African J. Biol. Sci., 15 (1): 289-304 (2019)

ISSN 1687-4870

www.ajbs.journals.ekb.eg

e- ISSN 2314-5501 (online)

e.mail: aasdjournal@yahoo.com

\title{
Protective effects of wheat and barley grasses on hepatotoxicity induced by tramadol in
} male rats

\author{
Lamiaa M. Abd EL-Maoula* \\ Nutrition and Food Science Department, Faculty of Home Economics, Al- Azhar University, \\ Tanta, Egypt \\ *dr_lamiaamostafa@azhar.edu.eg
}

\begin{abstract}
Nowadays tramadol is becoming abused more popular among teens in most countries worldwide; especially between males. The aim of the present study was to investigate the protective effects of barley and wheat grasses on hepatotoxicity induced by tramadol in male rats. Thirty male albino rats weighing (150-200 g) were divided into two main groups: The first group (5 rats) was fed on basal diet and kept as a negative group (G-). The second group (25rats) was fed on basal diet and administrated tramadol $(30 \mathrm{mg} / \mathrm{kg} /$ day) orally for 30 days. After that, the rats were divided into five subgroups as following: Subgroup (1): kept as a positive group $(\mathrm{G}+)$. Subgroups ( $2 \& 3)$ were given tramadol +wheat grass $(250$ and $500 \mathrm{mg} / \mathrm{kg}$ body weight) and Subgroups (4\&5) were given tramadol + barley grass (250 and $500 \mathrm{mg} / \mathrm{kg}$ body weight) orally for 30 days. The biochemical data showed elevated liver enzymes; alanine transaminase (ALT), aspartate transaminase (AST), Alkaline Phosphatase (ALP), total bilirubin, direct bilirubin and in direct bilirubin as well as liver weight in tramadol group $(\mathrm{G}+)$. A significant increase in malondialdehyde (MDA) and nitric oxides (NO) were also noticed in $(\mathrm{G}+)$. While, there were a significant decrease in glutathione peroxidase (GPx), reduced glutathione $(\mathrm{GSH})$ and catalase (CAT) levels in tramadol group (G+). Concomitant use of barley and wheat grass with tramadol induced improvement in the hepatotoxic effects. The best results were recorded for the groups treated with high dose $(500 \mathrm{mg} / \mathrm{kg}$ body weight $)$ of barley and wheat grass. It was concluded from the present results that administration of barley and wheat grass with tramadol can ameliorating tramadol-induced hepatotoxicity which might be due to its antioxidant potential.
\end{abstract}

Keywords: Hepatotoxicity, tramadol, liver enzymes, antioxidant enzymes, barley grass, wheat grass.

\section{INTRODUCTION}

Tramadol is a synthetic opioid analgesic that acts centrally and is used to treat moderate to severe pain (Pinho et al., 2013). Tramadol works as an analgesic by limiting serotonin and norepinephrine reuptake as well as binding to $\mu$-opioid receptors (Grond and Sablotzki, 2004). Tramadol usage can lead to serotonin syndrome (SS), a severe illness characterised by altered mental status, agitation, tremors, dilated eye pupils, and enhanced reflexes caused by excessive serotonergic activity (Takeshita and Litzinger, 2009). Tramadol is primarily metabolised in the liver by the enzymes cytochrome P450, cytochrome P4503A, and cytochrome $\mathrm{P} 450$ isozyme, where it is $\mathrm{O}$ and $\mathrm{N}$-demethylated to five various metabolites then being conjugated with glucuronic acid and sulphate (Raffa, 2008). O-desmethyl tramadol is the most active metabolite with more potent pharmacological activity when compared to the parent tramadol substance (Barbosa et al., 2016). Tramadol is metabolized in the 


\section{Lamiaa M. Abd EL-Maoula et al.}

liver and then eliminated mostly by the kidneys; as a result, these organs are regarded to be the primary target organs for tramadol poisoning (Barbosa et al., 2017). The hazardous effects of tramadol should be considered during long-term treatment, especially at high doses (Watson et al., 2004). Due to the sheer widespread usage of tramadol, hepatotoxicity is a clinical and economic concern (Janssen-Ortho, 2005).

Ninety percent of the population is affected by oxidative stress, which manifests itself in the form of arthritis, ischemia, neurodegeneration, and chronic liver disease.

In the last few years, tramadol consumption has become more common in Egypt and other Middle Eastern countries. This could be due to its low cost and widespread availability (Fawzi, 2011).

For thousands of years, cereal grass has been used to treat a variety of diseases. In the last ten years, human intake of wheat grass and other cereal grasses has expanded considerably (Jain and Argal, 2014). Wheat grass (Triticum aestivum) contains a lot of vitamins, minerals, amino acids, chlorophyll and enzymes. Fresh juice has been demonstrated to have anti-inflammatory, anti-ulcer, antioxidant, anti-cancer, and antiarthritic properties. Wheat grass is said to aid blood flow, digestion, and general detoxifying of the body so it contains physiologically active chemicals and minerals, as well as antioxidants (Chauhan, 2014). Wheat grass is used in herbal system of medicine and described as antioxidant, immunomodulatory, ant-ibacterial, astringent, diuretic, laxative, colitis, acidity and kidney malfunction (Ashok, 2011). Wheat grass offers a number of healthpromoting properties. It is well-known for its therapeutic properties. It is used as a purifying and cleansing agent, and due of its nutritional value, it can also be called a body builder (Shaikh and Majaz, 2016). Wheat grass is a primary source of several nutrients, including bioflavonoids, chlorophyll, phenol compounds, iron, magnesium, calcium, amino acids and vitamins $\mathrm{A}, \mathrm{B}, \mathrm{C}$, and $\mathrm{E}$, all of which play a role in disease prevention (Durairaj et al., 2014). At the same time, Wheat grass contains anti-cancer compounds such as laetrile and selenium, as well as cytochrome oxidase, superoxide dismutase (SOD) and mucopolysaccharide (Wheat and Currie, 2008).

Barley (Hordeum vulgare L.) is the world's fourth most significant cereal crop and contains the highest amount of dietary fiber; its malt is used in functional foods. Based on phytochemicals such as flavonoids, $\beta$-glucan, tocols, lignans, phytosterols, phenolic acids, and folate, regular consumption of whole grain barley and its hydroalcoholic extract lowers the risk of chronic diseases (cancer, obesity, cardiovascular disease, diabetes, and etc.) (Idehen et al., 2017).

Lee et al. (2016) indicated that Hordeum vulgare L. is the source of antioxidants and naturally beneficial substances in its bran, leaves, seeds and sprouts. Consumption of barley, which includes many medicinally active phytocompounds and a wide range of vitamins, eight essential amino acids and minerals, is usually connected with improved health (Lahouar et al., 2015). Barley grass, which is the young leaves of barley picked about 10 days after sowing the seeds, has gotten a lot of attention recently as a functional food. The highest nutrient concentrations are found in the green mass during a brief time of vegetation, and the nutritional profiles of green cereal plants alter rapidly as they expand (Ehrenbergerová et al., 2007). It has also been observed that barley young leaves have antihypertensive, depressive, antidiabetic, and cancerprevention capabilities, as well as reducing 
inflammation and pain by functioning as a free radical scavenger (Seo et al., 2013).

The purpose of this research was to investigate the potential protective effects of wheat and barley grasses due to their biologically active compounds and antioxidant abilities against tramadol induced hepatotoxicity in male rats.

\section{MATERIALS AND METHODS \\ Materials:}

1- Barley grass and wheat grass weren obtained from Sakha Research Center (Kafr Elsheikh, Egypt).

2- Tramadol tablets, each contains $225 \mathrm{mg}$ tramadol hydrochloride were obtained from October Pharma Company (Giza, Egypt).

3- Thirty normal male albino rats of Sprague Dawley Strain weighing (150 to 200 gm.) were obtained from the experimental animal house in Food Technology Research Institute, Agric. Res. Center, Giza, Egypt.

\section{Methods:}

Preparation of Wheat and Barely grass powder:

Wheat and barley grains were first cleaned and eliminated from dust, broken particles, and other foreign materials and then soaked overnight in water to be cultivated in a container. The soaked seeds were individually spread on wet jute bags, covered by muslin cloth and one more wet jute bag. Then, the seeds were sprinkled by water every $12 \mathrm{hr}$. till finishing the germination period. After the ninth day grasses were harvested and chopped with knife. It was dried in shade and powdered with a mechanical grinder. The powder was passed through sieve no.40 and stored in a labeled airtight container for study (Jain and Argal, 2014).

\section{Experimental Design}

Thirty healthy adult male albino rats "Sprague Dawley strain" weighing (150 to $200 \mathrm{~g}$ ) were kept in single wire cages with wire bottoms under hygienic conditions. Rats were divided into two main groups:

The first group (5 rats) was fed on basal diet and administrated distilled water orally for 30 days and kept as a negative control group (G-).

The second group (25 rats): was fed on basal diet and administrated orally tramadol at dose $(30 \mathrm{mg} / \mathrm{kg} / \mathrm{day})$, for 30 days to induce hepatotoxicity. This dose is $1 / 10$ of LD50. LD50 is $286-300 \mathrm{mg} / \mathrm{kg}$ (El-khateeb et al., 2015). After that, these rats were divided into five subgroups (each consisted of 5 rats) as follows:

Subgroup (1): rats were orally administrated tramadol $(30 \mathrm{mg} / \mathrm{kg} /$ day $)$ for 30 days and Kept as a positive control group (G+).

Subgroup (2): rats were orally administrated tramadol (30mg/kg/day) + barley grass $(250 \mathrm{mg} / \mathrm{kg} /$ day $)$.

Subgroup (3): rats were orally administrated tramadol (30mg/kg/day) + barley grass $(500 \mathrm{mg} / \mathrm{kg} /$ day).

Subgroup (4): rats were administrated tramadol $(30 \mathrm{mg} / \mathrm{kg} /$ day $)+$ wheat grass $(250 \mathrm{mg} / \mathrm{kg} /$ day).

Subgroup (5): rats were administrated tramadol (30mg/kg/day) + barley grass $(500 \mathrm{mg} / \mathrm{kg} /$ day $)$.

Rats received orally wheat and barley grasses for 30 days at doses (250 or $500 \mathrm{mg} / \mathrm{kg} /$ day). These doses were freshly prepared, suspended in distilled water before taken orally (Abed et al., 2017).

\section{Biological evaluation:}

At the end of the experiment, feed intake, body weight gain, liver weight as a percent of total body weight were determined according to Chapman et al. (1959), as follow: 


\section{Lamiaa M. Abd EL-Maoula et al.}

Feed intake $=$ Initial diet weight $(\mathrm{g})-$ left over diet weight $(\mathrm{g})$,

Body weight gain percent $($ BWG \% $)=\{($ Final body weight - Initial body weight)/Initial body weight $\}$ x 100 ,

Relative liver weight $=$ (liver weight $/$ Final body weight $) \times 100$.

The feed efficiency ratio was calculated according to Hosoya (1980) as follow:

FER=Body weight gain $(\mathrm{g}) /$ total feed intake $(\mathrm{g})$.

Liver was removed from each rat, carefully washed with saline solution, dried with filter paper and weighted based on Drury and Wallington (1980).

\section{Biochemical analysis:}

Determination of the activity of liver enzymes:

Alanine aminotransferase (ALT) and Aspartate aminotransferase (AST) were determined in the serum according to Reitman and Frankel (1957). Alkaline phosphatase (ALP) determination was performed according to Roy (1970).

\section{Determination of serum Bilirubin:}

The total bilirubin was determined in serum according to Doumas et al. (1973). Direct Bilirubin was determined in serum according to Chary and Sharm (2004). Serum Indirect Bilirubin was calculated according to Chary and Sharm (2004) equation:

Indirect Bilirubin $(\mathrm{g} / \mathrm{dL})=$ Total Bilirubin $(\mathrm{g} / \mathrm{dL})$ Direct Bilirubin (g/dL).

\section{Determination of serum proteins:}

The total protein (T.P) was determined according to Sonnenwirth and Jaret (1980). Albumin was determined according to the method of Drupt (1974) as modified by, Spencer and Price (1977). Globulin was calculated according to Chary and Sharm (2004) equation:

Serum globulin $(\mathrm{g} / \mathrm{dL})=$ total protein $(\mathrm{g} / \mathrm{dL})$ Albumin (g/dL).

\section{Antioxidant enzymes in serum}

Glutathione peroxidase (GPx), Catalase (CAT), Nitric oxide (No) and Malondialdehyde (MDA) were determined in serum according to Moshage et al.(1995) and Ahmadvand et al. (2014).

\section{Antioxidant enzymes in liver tissue}

Catalase (CAT), reduced glutathione (GSH), Malondialdehyde (MDA) and Nitric oxide (No) were determined in liver tissue according to Green et al. (1982) and Aebi (1974).

\section{Statistical analysis}

Data were represented as means \pm standard deviation (SD). Differences were statistically analyzed by one-way analysis of variance (ANOVA test) using SPSS 16 software package and considered significant at $\mathrm{P}$ values $<0.05$ Armitage and Berry (1987).

\section{Biological evaluation}

RESULTS

Data listed in Table (1) showed the effect of wheat and barley grasses powder on feed intake (FI), body weight gain (BWG) \%, feed efficiency ratio (FER) and relative liver weight. All experimental groups treated with wheat and barley grasses powder recorded significant increase in FI and FER when compared to $(+\mathrm{ve})$ control group $\quad(17.13 \pm 0.56 \quad \& \quad 0.05 \pm 0.02$, respectively). On the other hand, the results of FI recorded non-significant differences between all treated groups and normal control group (G-). As for BWG \%, it could be observed that all experimental groups treated with wheat grass $(250 \& 500 \mathrm{mg} / \mathrm{kg})$ and barley grass $(500 \mathrm{mg} / \mathrm{kg})$ had significant increase compared to tramadol group. The best results for BWG were recorded for the groups treated with wheat and grasses powder $(500 \mathrm{mg} / \mathrm{kg})$. While 
group treated with wheat grass $(250 \mathrm{mg} / \mathrm{Kg})$ recorded the best result for FER.

Table (1) also, illustrate the change in relative liver weight $\%$ for controls and treated groups. Results of relative liver Table (1). Effects of wheat and barley grasses powder on feed intake (FI), body weight gain (BWG), feed efficiency ratio (FER) and relative liver weight \% in male rats.*

\begin{tabular}{|c|c|c|c|c|}
\hline \multirow{2}{*}{ Groups } & \multicolumn{3}{|c|}{ Parameters } \\
\cline { 2 - 5 } & FI (g) & BWG $(\boldsymbol{\%})$ & FER & $\begin{array}{c}\text { Relative } \\
\text { Liver weight } \\
\text { \% }\end{array}$ \\
\hline Control +ve & $18.9 . \pm 0.23^{\mathrm{b}}$ & $30.71 \pm 4.02^{\mathrm{e}}$ & $0.16 \pm 0.02^{\mathrm{e}}$ & $2.06 \pm 0.16^{\mathrm{a}}$ \\
\hline Control +ve & $17.13 \pm 0.56^{\mathrm{a}}$ & $22.00 \pm 3.68^{\mathrm{a}}$ & $0.05 \pm 0.02^{\mathrm{a}}$ & $3.17 \pm 0.17^{\mathrm{b}}$ \\
\hline Tramadol + wheat grass (250mg/Kg) & $19.26 \pm 0.15^{\mathrm{b}}$ & $24.38 \pm 4.53^{\mathrm{b}}$ & $0.12 \pm 0.02^{\mathrm{d}}$ & $2.06 \pm 0.20^{\mathrm{a}}$ \\
\hline Tramadol + wheat grass (500mg/kg) & $19.22 \pm 0.25^{\mathrm{b}}$ & $28.21 \pm 5.98^{\mathrm{de}}$ & $0.09 \pm 0.02^{\mathrm{c}}$ & $2.16 \pm 0.10^{\mathrm{a}}$ \\
\hline Tramadol + barley grass (250mg/kg) & $18.9 \pm 0.19^{\mathrm{b}}$ & $22.57 \pm 1.23^{\mathrm{a}}$ & $0.08 \pm 0.01^{\mathrm{c}}$ & $2.08 \pm 0.40^{\mathrm{a}}$ \\
\hline Tramadol + barley grass $\mathbf{( 5 0 0 m g / k g )}$ & $19.02 \pm 0.24^{\mathrm{b}}$ & $25.43 \pm 2.20^{\mathrm{c}}$ & $0.07 \pm 0.01^{\mathrm{b}}$ & $2.37 \pm 0.19^{\mathrm{a}}$ \\
\hline
\end{tabular}

$*$ Data are presented as mean \pm SD. Values with different letters indicate significant differences among groups at $\mathrm{p} \leq 0.05$.

\section{Liver function}

Data presented in Table (2) declared that all treated groups showed a significant reduction in ALT, AST and ALP (U/L) as compared to the positive control group. The best results for ALT were recorded for the weight $(\%)$ showed that all treated groups had significant decrease in mean values when compared with (+ve) control group (3.17 \pm 0.17$)$.

Table (2). Effects of wheat and barley grasses powder on liver enzymes (ALT, AST \& ALP) in male rats.*

\begin{tabular}{|c|c|c|c|}
\hline \multirow{2}{*}{ Groups } & \multicolumn{3}{|c|}{ Parameters } \\
\cline { 2 - 4 } & ALT(U/L) & AST(U/L) & ALP(U/L) \\
\hline Control -ve & $48.36 \pm 1.83^{\mathrm{a}}$ & $93.80 \pm 1.26^{\mathrm{a}}$ & $117.20 \pm 2.36^{\mathrm{a}}$ \\
\hline Control +ve & $145.20 \pm 1.93^{\mathrm{d}}$ & $277.87 \pm 3.19^{\mathrm{f}}$ & $263.20 \pm 2.23^{\mathrm{e}}$ \\
\hline Tramadol + barley grass $(\mathbf{2 5 0 m g} / \mathbf{k g})$ & $64.63 \pm 2.90^{\mathrm{c}}$ & $124.40 \pm 3.62^{\mathrm{e}}$ & $137.60 \pm 2.11^{\mathrm{d}}$ \\
\hline Tramadol + barley grass $(\mathbf{5 0 0 m g} / \mathbf{k g})$ & $54.27 \pm 1.57^{\mathrm{b}}$ & $110.33 \pm 2.33^{\mathrm{c}}$ & $132.83 \pm 2.35^{\mathrm{c}}$ \\
\hline Tramadol + wheat grass $(\mathbf{2 5 0} \mathrm{mg} / \mathbf{K g})$ & $61.77 \pm 2.02^{\mathrm{c}}$ & $118.53 \pm 3.00^{\mathrm{d}}$ & $131.45 \pm 2.73^{\mathrm{c}}$ \\
\hline Tramadol + wheat grass $(\mathbf{5 0 0} \mathrm{mg} / \mathbf{k g})$ & $53.27 \pm 2.54^{\mathrm{b}}$ & $99.63 \pm 1.56^{\mathrm{b}}$ & $123.43 \pm 2.31^{\mathrm{b}}$ \\
\hline
\end{tabular}

*Data are presented as mean \pm SD. Values with different letters indicate significant differences among groups at $\mathrm{p} \leq 0.05$.

It was obvious that the mean values of T.B, D.B and ID.B (mg/dl) of (-ve) control group were lower than those of (+ve) control group, with significant difference between them. The treated groups showed a significant reduction in their mean values of T.B, D.B and ID.B (mg /dl) as compared to groups treated with wheat or barley grasses $(500 \mathrm{mg} / \mathrm{kg})$. While those treated with wheat grass $(500 \mathrm{mg} / \mathrm{kg})$ recorded the best result for AST and ALP (99.63 $\pm 1.56 \&$ $123.43 \pm 2.31$, respectively). 


\section{Lamiaa M. Abd EL-Maoula et al.}

recorded the same value of D.B from those

of normal control group (Table 3).

Table (3). Effects of wheat and barley grasses powder on total bilirubin, direct bilirubin and in direct bilirubin in male rats.*

\begin{tabular}{|c|c|c|c|}
\hline \multirow{2}{*}{ Groups } & \multicolumn{3}{|c|}{ Parameters } \\
\cline { 2 - 4 } & $\begin{array}{c}\text { T.B } \\
(\mathbf{m g} / \mathbf{d L})\end{array}$ & D.B (mg/dL) & ID.B (mg/dL) \\
\hline Control -ve & $0.56 \pm 0.03^{\mathrm{a}}$ & $0.14 \pm 0.01^{\mathrm{a}}$ & $0.43 \pm 0.03^{\mathrm{a}}$ \\
\hline Control +ve & $1.10 \pm 0.05^{\mathrm{e}}$ & $0.21 \pm 0.02^{\mathrm{d}}$ & $0.89 \pm 0.04^{\mathrm{e}}$ \\
\hline Tramadol + wheat grass $(\mathbf{2 5 0} \mathrm{mg} / \mathbf{K g})$ & $0.78 \pm 0.03^{\mathrm{c}}$ & $0.16 \pm 0.01^{\mathrm{bc}}$ & $0.62 \pm 0.02^{\mathrm{c}}$ \\
\hline Tramadol + wheat grass $(\mathbf{5 0 0} \mathrm{mg} / \mathbf{k g})$ & $0.68 \pm 0.03^{\mathrm{b}}$ & $0.14 \pm 0.02^{\mathrm{ab}}$ & $0.54 \pm 0.02^{\mathrm{b}}$ \\
\hline Tramadol + barley grass $(\mathbf{2 5 0} \mathrm{mg} / \mathbf{k g})$ & $0.90 \pm 0.07^{\mathrm{d}}$ & $0.18 \pm 0.01^{\mathrm{c}}$ & $0.72 \pm 0.06^{\mathrm{d}}$ \\
\hline Tramadol + barley grass $(\mathbf{5 0 0 m g} / \mathbf{k g})$ & $0.74 \pm 0.03^{\mathrm{bc}}$ & $0.16 \pm 0.01^{\mathrm{bc}}$ & $0.58 \pm 0.04^{\mathrm{bc}}$ \\
\hline
\end{tabular}

*Data are presented as mean \pm SD. Values with different letters indicate significant differences among groups at $\mathrm{p} \leq 0.05$.

\section{Serum protein}

Table (4) illustrates the change in the total protein, albumin and globulin (mg/dl) for controls and treated groups. Results of the total protein, albumin and globulin showed that (+ve) control group recorded mean value $(3.79 \pm 0.06,2.84 \pm 0.12$ $\& 0.95 \pm 0.05$, respectively) which are less than those of all the treated groups which had significant increase in this parameter.
Numerically the best results for the total protein, albumin and globulin were recorded for the groups treated with wheat grass $(500 \mathrm{mg} / \mathrm{kg})$, which recorded the nearest value of those of normal control group. Results of $\mathrm{A} / \mathrm{G}$ ratio showed that all the treated groups had significant decrease in their mean values when compared with (+ve) control group $(2.99 \pm 0.29)$.

Table (4). Effects of wheat and barley grasses powder on serum protein in male rats.*

\begin{tabular}{|c|c|c|c|c|}
\hline \multirow[b]{2}{*}{ Groups } & \multicolumn{4}{|c|}{ Parameters } \\
\hline & $\begin{array}{c}\text { Total } \\
\text { protein } \\
\text { (g/dl) }\end{array}$ & $\begin{array}{l}\text { Albumin } \\
\text { (g/dl) }\end{array}$ & $\begin{array}{l}\text { Globulin } \\
\text { (dl g/) }\end{array}$ & A/ G Ratio \\
\hline Control-ve & $8.99 \pm 0.15^{\mathrm{e}}$ & $5.07 \pm 0.06^{\mathrm{e}}$ & $3.92 \pm 0.08^{\mathrm{e}}$ & $1.30 \pm 0.01^{\mathrm{a}}$ \\
\hline Control +ve & $3.79 \pm 0.06^{\mathrm{a}}$ & $2.84 \pm 0.12^{\mathrm{a}}$ & $0.95 \pm 0.05^{\mathrm{a}}$ & $2.99 \pm 0.29^{b}$ \\
\hline Tramadol + wheat grass $(250 \mathrm{mg} / \mathrm{Kg})$ & $7.3 \pm 0.02^{\mathrm{c}}$ & $4.17 \pm 0.03^{\mathrm{c}}$ & $3.13 \pm 0.04^{\mathrm{bc}}$ & $1.33 \pm 0.03^{\mathrm{a}}$ \\
\hline Tramadol + wheat grass $(500 \mathrm{mg} / \mathrm{kg})$ & $8.25 \pm 0.46^{\mathrm{d}}$ & $4.68 \pm 0.28^{\mathrm{d}}$ & $3.57 \pm 0.19^{\mathrm{d}}$ & $1.31 \pm 0.01^{\mathrm{a}}$ \\
\hline Tramadol + barley grass $(250 \mathrm{mg} / \mathrm{kg})$ & $6.73 \pm 0.37^{b}$ & $3.84 \pm 0.08^{b}$ & $2.88 \pm 0.34^{\mathrm{b}}$ & $1.34 \pm 0.16^{\mathrm{a}}$ \\
\hline Tramadol + barley grass $(500 \mathrm{mg} / \mathrm{kg})$ & $7.43 \pm 0.27^{\mathrm{c}}$ & $4.21 \pm 0.12^{\mathrm{c}}$ & $3.22 \pm 0.15^{\mathrm{c}}$ & $1.31 \pm 0.03^{\mathrm{a}}$ \\
\hline
\end{tabular}

*Data are presented as mean \pm SD. Values with different letters indicate significant differences among groups at $\mathrm{p} \leq 0.05$.

\section{Oxidative markers and antioxidants levels in serum}

From Table (5) as a result of administration of tramadol $30 \mathrm{mg} / \mathrm{kg} / \mathrm{d}$, there were a marked reduction in the levels of some antioxidants in serum such as catalase (CAT) and glutathione peroxidase (GPX) as compared to (-ve) control 
group. Also, there were significant increase for nitric oxides (NO) and Malondialdehyde (MDA) for tramadol group as compared to normal control. On the other hand, all experimental groups

Table (5). Effects of wheat and barley grasses powder on antioxidant enzymes (NO, MDA, CAT and GPX) in serum of male rats.*

\begin{tabular}{|c|c|c|c|c|}
\hline \multirow[b]{2}{*}{ Groups } & \multicolumn{4}{|c|}{ Parameters } \\
\hline & $\begin{array}{c}\mathrm{NO} \\
(\mathrm{nmol} / \mathrm{ml})\end{array}$ & $\begin{array}{c}\text { MDA } \\
(\mathbf{n m o l} / \mathbf{m l})\end{array}$ & $\begin{array}{c}\text { CAT } \\
\text { (ng/ml) }\end{array}$ & $\begin{array}{c}\mathbf{G P X} \\
(\mathbf{n g} / \mathbf{m l})\end{array}$ \\
\hline Control-ve & $43.88 \pm 0.88^{\mathrm{a}}$ & $46.50 \pm 3.50^{\mathrm{a}}$ & $53.50 \pm 3.50^{\mathrm{d}}$ & $39.00 \pm 2.00^{d}$ \\
\hline Control +ve & $92.50 \pm 2.50^{\mathrm{e}}$ & $117.50 \pm 2.50^{\mathrm{e}}$ & $30.00 \pm 2.00^{\mathrm{a}}$ & $12.50 \pm 1.50^{\mathrm{a}}$ \\
\hline Tramadol + wheat grass $(25$ & $76.50 \pm 6.50^{\mathrm{d}}$ & $83.00 \pm 3.00^{\mathrm{d}}$ & $34.00 \pm 1.00^{\mathrm{ab}}$ & $20.00 \pm 2.00^{\mathrm{b}}$ \\
\hline Tramadol + wheat grass $(500 \mathrm{mg} / \mathrm{kg})$ & $61.25 \pm 0.75^{\mathrm{c}}$ & $74.50 \pm$ & $43.50 \pm 1.50^{\mathrm{c}}$ & $29.00 \pm 1.00^{\mathrm{c}}$ \\
\hline Tramadol + barley grass $(250 \mathrm{mg} / \mathrm{kg})$ & $73.75 \pm 2.75^{\mathrm{d}}$ & $58.00 \pm 2.00^{\mathrm{b}}$ & $37.50 \pm 2.50^{\mathrm{b}}$ & $22.50 \pm 2.50^{\mathrm{b}}$ \\
\hline Tramadol + barley grass $(500 \mathrm{mg} / \mathrm{kg})$ & $51.25 \pm 1.25^{\mathrm{b}}$ & $48.50 \pm 1.50^{\mathrm{a}}$ & $52.00 \pm 3.00^{\mathrm{d}}$ & $32.50 \pm 2.50^{\mathrm{c}}$ \\
\hline
\end{tabular}

*Data are presented as mean \pm SD. Values with different letters indicate significant differences among groups at $p \leq 0.05$.

\section{Oxidative markers and antioxidants levels in liver tissues}

Table (6) shows that the mean values of NO and MDA in liver tissues had, high significant increase in positive control group $(89.70 \pm 2.50 \& 156.73 \pm 2.41)$ respectively) when compared to the normal rats $(33.18 \pm 2.70$ \& $57.14 \pm 2.08$, respectively). All treated groups showed showed a significant reduction in NO and MDA and significant increase in GPX and CAT as compared to positive control group. significant decrease in $\mathrm{NO}$ and MDA as compared to tramadol group. While all experimental groups showed significant increase in CAT and GSH when compared with (+ve) control group. The best result for (NO, MDA, CAT and GSH) in liver tissues were recorded for the group treated with wheat grass $(500 \mathrm{mg} / \mathrm{kg})$.

Table (6). Effects of wheat and barley grasses powder on antioxidant enzymes (NO, MDA, CAT and GSH) in liver tissues in rats.*

\begin{tabular}{|c|c|c|c|c|}
\hline \multirow{2}{*}{ Groups } & \multicolumn{4}{|c|}{ Parameters } \\
\cline { 2 - 5 } & $\begin{array}{c}\text { NO } \\
(\mathbf{n m o l} / \mathbf{m g})\end{array}$ & $\begin{array}{c}\text { MDA } \\
(\mathbf{n m o l} / \mathbf{m g})\end{array}$ & $\begin{array}{c}\text { CAT } \\
(\mathbf{n g} / \mathbf{m g})\end{array}$ & $\begin{array}{c}\text { GSH } \\
(\mathbf{n g} / \mathbf{m g})\end{array}$ \\
\hline Control -ve & $33.18 \pm 2.70^{\mathrm{a}}$ & $57.14 \pm 2.08^{\mathrm{a}}$ & $62.88 \pm 2.08^{\mathrm{e}}$ & $9.44 \pm 0.51^{\mathrm{f}}$ \\
\hline Control +ve & $89.70 \pm 2.50^{\mathrm{f}}$ & $156.73 \pm 2.41^{\mathrm{e}}$ & $15.29 \pm 0.30^{\mathrm{a}}$ & $1.70 \pm 0.17^{\mathrm{a}}$ \\
\hline Tramadol + wheat grass $(\mathbf{2 5 0} \mathbf{m g} / \mathbf{K g})$ & $52.43 \pm 2.85^{\mathrm{c}}$ & $80.33 \pm 2.00^{\mathrm{c}}$ & $40.03 \pm 1.85^{\mathrm{c}}$ & $5.71 \pm 0.42^{\mathrm{d}}$ \\
\hline Tramadol + wheat grass $\mathbf{5 0 0 m g / k g})$ & $41.96 \pm 1.48^{\mathrm{b}}$ & $65.37 \pm 4.22^{\mathrm{b}}$ & $54.14 \pm 1.83^{\mathrm{d}}$ & $7.17 \pm 0.07^{\mathrm{e}}$ \\
\hline Tramadol + barley grass (250mg/kg) & $73.37 \pm 2.01^{\mathrm{e}}$ & $108.44 \pm 3.00^{\mathrm{d}}$ & $24.11 \pm 1.34^{\mathrm{b}}$ & $3.76 \pm 0.12^{\mathrm{b}}$ \\
\hline Tramadol + barley grass (500mg/kg) & $59.51 \pm 1.78^{\mathrm{d}}$ & $83.74 \pm 1.88^{\mathrm{c}}$ & $37.44 \pm 1.96^{\mathrm{c}}$ & $4.96 \pm 0.23^{\mathrm{c}}$ \\
\hline
\end{tabular}

*Data are presented as mean \pm SD. Values with different letters indicate significant differences among groups at $\mathrm{p} \leq 0.05$.

\section{DISCUSSION}

Tramadol belong to the same family of codeine, morphine and oxycodone (Niesters et al., 2013). It is a powerful 


\section{Lamiaa M. Abd EL-Maoula et al.}

addition to the high risk of tramadol addiction; it causes hepatotoxicity and nephrotoxicity (Janssen-Ortho, 2005).

Body and organ weights are important indices for drug toxicological evaluations because they might be influenced by drug-induced toxicity (Bailey et al., 2004). The present results demonstrated that tramadol induced decrease in body weight gain $\%$, feed intake and feed efficiency ratio. The decrease occurred in the positive control group are attributed to tramadol abuse which led to some intestinal disturbances such vomiting, nausea and constipation with changing in appetite (Grond and Sablotzki, 2004). Oka et al. (2015) mentioned that administration of Tramadol inhibits the appetite centers in the hypothalamus, which could explain the tramadol group's decreased food consumption.

On the other hand, all rats given wheat and barley grasses, showed improvement in their body weight gain \%, feed intake and feed efficiency ratio which confirm the ability of the examined samples to alleviate the toxicity of tramadol. Ikeguchi et al. (2014) cleared that adding barley leaf powder in the diet increased the fecal weight as it contains water-soluble dietary fibers and stimulating gastrointestinal tract by lowering $\mathrm{pH}$. Jorige and Akula (2015) reported that regular consumption of the wheat grass can develop the gastrointestinal system. Wheat grass juice reduces body weight as it contains selenium which improves function of the thyroid gland and contains potassium which aspects in coming off of water weight, so that, managing body weight. Also, wheat grass blocks the stomach, thus suppressing the appetite (Husain et al., 2017).

Estimating relative organ weights is a crucial aspect of the toxicological evaluation of chemical compounds. In the present study there were no significant differences in relative liver weights between the tramadol and other groups. Lakshmi et al. (2015) reported that treatment with wheat grass extract before arsenic intoxication considerably reduced the body weight, kidney and liver weights of experimental rats following arsenic intoxication. Foda (2010) mentioned that adding young green barley leaves powder might improve kidney, liver and heart weight.

In the current study, the liver function markers were significantly increased in tramadol group compared with the normal control one. This increase could be attributed to increased lipid peroxidation in hepatic tissues, which affects the function and structure of cell membranes, leading to increased leakage of these enzymes from hepatocytes into the blood stream (Salahshoor et al., 2016). In this context, several researches reported that exposure to tramadol resulting in elevated liver enzyme activities (Barbosa et al., 2017). Atici et al. (2005) reported that Long-term tramadol use resulted in significant increases in serum LDH (lactate dehydrogenase), AST and ALT levels in rats. As the increased secretion of these liver enzymes is often accompanied with acute cell necrosis, the elevated plasma level of these enzymes in tramadol-treated rats could be attributable to necrosis or damage to the liver cell membrane, allowing the enzymes to escape into the blood stream (Loughrey et al., 2003).

It was clear from the current investigation that administration of barley and wheat grasses improved liver parameters. Daily consumption of barley grass powder enhances liver function and immunity; has hypolipidemic and loses weight; anticancer and anti-inflammatory effects; prevents heart disease (Zuo et al., 2017).

Saponarin-rich barley sprouts protect the liver by reducing the inflammatory 
response caused by alcohol consumption (Lee et al., 2016). Saponarin demonstrated antioxidation and hepatoprotection against $\mathrm{CCl}_{4}$-induced liver injury in vitro and in vivo (Simeonova et al., 2014).

By activating nuclear factor erythroid 2-related factor 2 (Nrf2) and increasing glutathione synthesis, barley sprout extract protects liver cells from oxidative stress, inhibiting glutathione depletion and hepatic lipid build up, as well as reducing serum biochemical indicators of liver injury and inhibiting inflammatory responses (Lee et al., 2017).

Wheat grass juice has various enzymes that help to cleanse the body of toxins and pollutants, and amino acids help to detoxify the liver and eliminate toxic heavy metals from the blood stream, eliminate waste from the body, and slow down the ageing process (Sareen et al., 2014). It was documented that wheat sprouts produce some physiologically active phytochemicals during germination; wheat grass leaf extract impacts liver enzyme activity and lipid peroxidation (Calzuola et al., 2004). Fresh wheat grass juice had a hepatoprotective effect in $\mathrm{CCl}_{4}$-treated rats. With a dose of $100 \mathrm{mg} / \mathrm{kg} /$ day, it showed a strong hepatoprotective impact in terms of ALP, SGPT, SGOT and Bilirubin in serum (Jain et al., 2007). Kamboj et al. (2011a) reported that depending on the amount of wheat grass, it prevents a rise in liver enzymes.

Notably, the serum total protein, albumin and globulin (mg/dl) were markedly decreased in tramadol treated rats compared with the control group in the present study. In a tramadol-induced lethal overdose with liver failure, albumin levels were found to be lower (Loughrey et al., 2003). Also, serum albumin and total proteins were found to be lower in opiumaddicted diabetic males (Asadikaram et al., 2004). Such results show that because these analytes are produced entirely or largely by the liver, the hepatic synthetic function is impaired (Yang et al., 2014). Khalaf (2017) reported that the due to oxidative stress and liver damage, tramadol treatment reduced total protein, albumin, and globulin levels.

In the present study, administration of barley grass and wheat grass increased the total protein, albumin and globulin in serum of rats. Increased protein may be due to phenols existing in the wheat grass might have successfully prohibited the cell membrane injury (Datta et al., 2012). Consumption wheat grass extract increased the total protein near normal (Lakshmi et al., 2015).

Tramadol's toxic action results in a high population of unquenched free radicals, resulting in oxidative stress. Inhibition of antioxidant enzymes catalase (CAT) and glutathione peroxidase (GPX) activities in serum of rats in this investigation supports this theory. The present study demonstrated that Tramadol induced hepatic oxidative damage by greatly increasing $(\mathrm{p}<0.05)$ lipid peroxidation (MDA), which was accompanied by a reduction in the activity of antioxidant enzymes GSH and CAT concentration. Tramadol or its metabolites may bind to transition metals, which act as cofactors for antioxidant enzymes, causing antioxidant enzymes to be inhibited (AbdelZaher et al., 2011). These findings were in agreement with the results of Barbosa et al. (2017). CAT, SOD and GSH are antioxidant enzymes that play a key role in the scavenging of oxidative free radicals (Kruidenier et al., 2003). The suppression of antioxidant enzymes identified in this study could be attributed to their exhaustion as a result of oxidative stress generated by tramadol administration. The current results agreed with those of Ahmed and Kurkar (2014), which indicated tramadol promoted lipid peroxidation and raised MDA levels. Awadalla and Salah-Eldin (2015) 


\section{Lamiaa M. Abd EL-Maoula et al.}

documented that tramadol usage induced oxidative stress through increasing MDA level, decreasing the activities, of GSH, CAT and SOD enzymes in both liver and kidney tissues.

The present study found that administration of barley and wheat grasses $(500 \mathrm{mg} / \mathrm{kg})$ improved antioxidant enzymes in serum and liver tissues of male rats. Polyphenols, flavonoids, vitamins, and volatile compounds are all natural antioxidants found in plants (Moon and Shibamoto, 2009).

Barley is one of the most stresstolerant crops, with the same genes encoding enzymes in the pathways that produce antioxidant metabolites in its flag leaftocopherol, glutathione, and succinate (Templer et al., 2017). Barley Superoxide dismutase, 2"-O-glucosyl isovitexin (2"-OGIV), and protoheme are all antioxidant phytonutrients found in barley grass (Choe et al., 2010). Antioxidant flavonoids (saponarin and lutonarin) have been extracted from young barley grass, with saponarin and lutonarin levels increasing with UV exposure (Ferreres et al., 2008). Saponarin, found in barley grass, has potent antioxidant properties that can help prevent diseases induced by oxidative stress, such as cancer, inflammation, and liver disease (Kamiyama and Shibamoto, 2012). Barley grass has many health effects, such as hypoglycemic, anticancer and preventive constipation, antioxidant, and antiinflammatory activities (Lahouar et al., 2015).

Wheat grass has many antioxidant compounds as selenium, provitamin A,C,E, Carotene, transhydrogenase and superoxide dismutase (SOD) cytochromeoxidase (Padalia et al., 2010). Wheat grass treatments have been shown to reduce oxidative stress and improve antioxidant levels (Kamboj et al., 2011b). Wheat grass has protective effect against the oxidative stress in diabetes ratseitherby preventing generation free radical or by stimulating endogenous antioxidant protection or both in body tissues (Shakya et al., 2012). Wheat grass contains both of enzymatic and nonenzymatic antioxidants so; it reduced the oxidative stress (Sachin et al., 2013). Wheat grass contains great amount of antioxidants, thus it can be administered as an antioxidant phytomedicine to treat the oxidative stress caused by chemotherapy (Sachin et al., 2013). Durairaj et al. (2014) found that administration of wheat grass to male rats improved antioxidant levels such as catalase, superoxide dismutase, glutathione peroxidase, reduced vitamin $\mathrm{C}$, vitamin $\mathrm{E}$, and glutathione, which had been lowered due to oxidative stress caused by alcohol. Wheat grasses extract obviously normalized antioxidant enzymes in liver and kidney tissues by detoxification of body cells from free radical (Lakshmi et al., 2015).

\section{Conclusions and recommendation}

Tramadol has side effects that have caused oxidative stress and induced hepatotoxicity in the investigated male rats. Wheat and barley grasses can alleviate biochemical changes, oxidative stress, and hepatotoxicity induced by tramadol due to their content of polyphenols and other antioxidant compounds. However, these evidences have to be tested on human before giving any recommendation towards using barley and wheat grasses to protect human against the hepatotoxicity that can be produced due to long administration of tramadol.

\section{REFERENCES}

Abdel-Zaher, A.O.; Abdel-Rahman, M.S. and Elwasei, FM. (2011). Protective effect of Nigella sativa oil against tramadol-induced tolerance and dependence in mice: role of nitric oxide and oxidative stress. 
Neurotoxicology, 32:725-733.

Abed, K.A.K.;Yaqoob, K.; Abdoh, A.O.O.; Mohammed, S.M.; Pankaj, T.; Hakeem, S.M.A. and Mamoon, H.S. (2017). Investigation of antigenotoxic potential of wheatgrass (Triticum aestivum) powder on cyclophosphamide induced genotoxicity and oxidative stress in mice. Austin J. Pharmacol. Therapeutics, 5(3):1-6.

Aebi, H. (1974). Methods of enzymatic analysis (Bergmeyer, H.U., ed), 2nd Ed., Verlag Chemie, Weinheim, 2:673-78.

Ahmadvand, H, Dehnoo G.M.; Cheraghi, R.; Rasoulian, B.; Ezatpour, B. and Azadpour M. (2014). Amelioration of altered serum, liver, and kidney antioxidant enzymes activities by sodium selenite in alloxan-induced diabetic rats. Rep. Biochem. Mol. Biol.,3:14-20.

Ahmed, M.A. and Kurkar, A. (2014). Effects of opioid (tramadol) treatment on testicular functions in adult male rats: the role of nitric oxide and oxidative stress. Clin. Exp. Pharmacol. Physiol., 41:317-323.

Armitage, P. and Berry, G. (1987). Statistical Methods in Medical Research Blackwell, Oxford, UK, 93-213.

Asadikaram, G.; Reisi, M.; Kaseb, A.A.; Khaksari, M.; Mohammadi, A. and Mahmoodi, M. (2004). Effects of opium addiction on some serum factors in addicts with non-insulindependent diabetes mellitus. Addict. Biol., 9:53-58.

Ashok, S.A. (2011). Phytochemical and pharmacological screening of wheatgrass juice (Triticum aestivum L.). Int. J. Pharma. Sci. Rev. Res., 9(1): 159-164.
Atici, S.; Cinel, I.; Cinel, L.; Doruk, N. and Eskandari, G. (2005). Liver and kidney toxicity in chronic use of opioids: an experimental long term treatment model. J. Biosci., 30: 245252.

Awadalla, E. and Salah-Eldin, A. (2015). Histopathological and molecular studies on tramadol mediated hepatorenal toxicity in rats. J. Pharm. Biolog. Sci.,10(6):90-102.

Bailey, S.A.; Zidell, R.H. and Perry, R.W. (2004). Relationships between organ weight and body/brain weight in the rat: what is the best analytical endpoint? Toxicologic Pathol., 32(4): 448- 466.

Barbosa, J.; Faria, J.; Queirós, O.; Moreira, R.; Carvalho, F. and Dinis-Oliveira, R.J. (2016). Comparative metabolism of tramadol and tapentadol: a toxicological perspective. Drug Metab. Rev., 48:577-592.

Barbosa, J.; Faria, J.; Leal, S.; Afonso, L.P.; Lobo, J.; Queiros, O.; Moreira, R.; Carvalho, F. and Dinis-Oliveira, R.J. (2017). Acute administration of tramadol and tapentadol at effective analgesic and maximum tolerated doses causes hepato- and nephrotoxic effects in Wistar rats. Toxicology, 389:118-129

Calzuola, I.; Valeria, M. and Gianfranceschi, G.L. (2004). Synthesis of antioxidants in wheat sprouts. J. Agric. Food Chem., 52:5201-5206.

Chapman, D.G.;Castilla, R. and Cambell, A.J. (1959). Evaluation of protein in food. In: Method for the Documentation of protein Efficiency Ratio. Can. J. Biochem. Physiol., 37:679-686.

Chary, T.M. and Sharma, H. (2004). Practical Biochemistry For Medical and Dental Students. Jaypee Brothers Medical Publishers (P) LTD, New 


\section{Lamiaa M. Abd EL-Maoula et al.}

Delhi.

Chauhan, M. (2014). A pilot study on wheat grass juice for its phytochemical, nutritional and therapeutic potential on chronic diseases. Int. J. Chem. Stud., 2(4): 27-34.

Choe, J.H.; Jang, A. and Choi, J.H. (2010). Antioxidant activities of lotus leaves (Nelumbo nucifera) and barley leaves (Hordeum vulgare) extracts. Food Sci. Biotechnol., 19(3):831-836.

Datta, G.; Basu, A.; Sen, M. and Nath, P. (2012). Role of a-tocopherol, $\beta$ carotene and ascorbic acid against alcohol induced hepatotoxicity: A comparative analysis. J. Pharm. Res., 5:2485-2488.

Doumas, B.T.; Ferry, B.W.; Sasse, E.A. and Straum JV. (1973). Clinica Aplicada Amposta. Spain. Clin. Chem., 19: 984- 993.

Drupt, F. (1974).Colorimetric method for determination of albumin. Pharm. Biol., 9: 777-779.

Drury, R.A. and Wallington, E.A. (1980). Carton's histological technique.5th Ed., Oxford University. UK.

Durairaj, V.; Hoda, M.; Shakya, G.; Baby, S. and Rajagopalan, R. (2014). Phytochemical screening and analysis of antioxidant properties of aqueous extract of wheat grass. Asian Pa J. Trop. Med., 7:53985404.

Ehrenbergerová, J.; Vaculová, K.; Paulícková, I.; Brezinová B.N.; Macuchová, S.; Kopácek, J.; Gabrovská, D.; Holasová, M.; Ouhrabková, J.; Rysová, J.; Fiedlerová, V.; Winterová, R. and Horáčková S. (2007). Different barley cultivars as a source of green mass for improving nutrient balance in human diet. In: A. Brandstetter (ed.) Raumberg, Austria. 91-94.
El-khateeb, S.;El-Khishina, I.; Megaheda, O. and Mazenb, F.(2015). Effect of Nigella sativa Linn oil on tramadolinduced hepato-and nephrotoxicity in adult male albino rats. Toxicol. Reports, 2: 512-519.

Fawzi, M.M. (2011). Some medicolegal aspects concerning tramadol abuse: the new Middle East youth plague 2010. An Egyptian overview. Egypt. J. Forensic Sci., 1:99-102.

Ferreres, F.; Andrade, P.B.;Valentão, P. and Gil-Izquierdo, A. (2008). Further knowledge on barley (Hordeum vulgare L.) leaves O-glycosyl-Cglycosyl flavones by liquid chromatography-UV diode-array detection-electrospray ionisation mass spectrometry. J. Chromatogr., A. 1182(1):56-64.

Foda, M. (2010). Biochemical studies on antioxidants extracted from young green barley leaves. Master of Science in Agricultre science (Biochemistry). Department of Biochemistry Faculty of Agriculture Benha Universty.

Green, L.C.;Wagner, D.A.; Glogowski, J.; Skipper, P.L.;Wishnok, J.S. and Tannenbaum, S.R.(1982). Analysis of nitrate, nitrite, and $[15 \mathrm{~N}]$ nitrate in biological fluids. Analyt. Biochem., 126(1):131-138.

Grond, S. and Sablotzki, A. (2004).Clinical pharmacology of tramadol. Clin. Pharma coki net, 43:879-923.

Hosoya, N. (1980). Determination of feed efficiency ratio . Cited in Hosoya, N.; Inami , S. and Goto , S., eds. Nutrition Experiments Using Small Animals. Daiichi Shuppan, Tokyo, Japanese, pp:71. 
Husain, N.; Trak, T. and Chauhan, D. (2017). Wheatgrass : herbal remedy for health and beauty. Flora and Fauna, 23:143-148.

Idehen, E.; Tang, Y. and Sang, S. (2017). Bioactive phytochemicals in barley. J. Food Drug Analysis, 25(1):148161.

Ikeguchi, M.; Tsubata, M.; Takano, A.; Kamiya, T.; Takagaki, K.; Ito, H.; Sugawa-Katayama, Y. and Tsuji, H. (2014). Effects of young barley leaf powder on gastrointestinal functions in rats and its efficacy-related physicochemical properties.

Evidence-Based Complementary and Alternative Medicine:1-7.

Jain, G. and Argal, A. (2014). Hepatoprotective potential of young leaves of Triticum aestivum Linn. against CCl4 induced hepatotoxicity. Int. J. Pharma. Sci. Res., 5(11):4751-4755.

Jain, G.; Argal, A.; Pathak, A.K.; Singh, V.K. and Kannojia, P. (2007). Hepatoprotective activity of wheatgrass juice. The pharmacist, 2(1): 29-30.

Janssen-Ortho, I. (2005).Tramacet: A Product Monograph. pp. 1-36 www.janssen-ortho.com.

Jorige, A. and Akula, A. (2015). Neuroprotective Role of Wheatgrass Powder in Experimental Diabetic Neuropathy via Modulating Oxidative Stress Markers in Rat Sciatic Nerves. Am. J. Phytomed. Clin. Therapeutics, 3(7):529-540.

Kamboj, J.K.; Rana, S.V.; Dhawan, D.K. and Vahiphei, K. (2011a). Role of wheatgrass in prevention of carbon tetrachloride induced hepatotoxicity in rats. J. Clin. Exper. Hepatol., 1:S1.

Kamboj, J.K.; Rana, S.V.; Ola, R.P.; Dhawan, D.K. and Vahiphei, K. (2011b). Wheatgrass and antioxidant levels in carbon tetrachloride induced hepatotoxicity in rats. $\mathrm{J}$. Clinical Exper. Hepatol., 1:S1.

Kamiyama, M. and Shibamoto, T. (2012). Flavonoids with potent antioxidant activity found in young green barley leaves. J. Agric. Food Chem., 60(25):6260-6267.

Khalaf, A.N. (2017). Silymarin extract modulates toxicity, injury, oxidative stress and PCNA alternations induced by tramadolin rat liver. J. Biosci. Appl. Res., 3 (1):28-35.

Kruidenier, L.; Kuiper, I.; Van-Duijn, W.; Mieremet-Ooms, M.A. and Van Hogezand, R.A. (2003). Imbalanced secondary mucosal antioxidant response in inflammatory bowel disease. J. Pathol., 201: 17-27.

Lahouar, L.; El-Bok, S. and Achour, L. (2015). Therapeutic potential of young green barley leaves in prevention and treatment of chronic diseases: An Overview. Am. J. Chinese Med., 43(7): 1311-1329.

Lakshmi, B.; Sudhakar, M.; Sudha, F. and Gopa, M. (2015). Ameliorative effect of Triticum aestivum Linn against experimentally induced arsenic toxicity in male albino rats. Scholars Research Library Der Pharmacia Lettre,7 (1):202-211.

Lee, Y.H.; Kim, S. and Lee, S. (2017). Antioxidant effect of barley sprout extract via enhancement of nuclear factor-erythroid 2 related factor 2 activity and glutathione synthesis. Nutrients, 9(11):1252.

Lee, Y.H.; Kim, J.K.; Kim, S.H.; Oh, .J.; Seo, W.D.; Kim, K.M.; Jung, .J. and Jung, Y.S. (2016). Barley sprouts extract attenuates alcoholic fatty liver injury in mice by reducing inflammatory response. Nutrients $\mathrm{J}$. 8(7):440.

Loughrey, M.B.; Loughrey, C.M.; Johnston, S. and O'Rourke, D. (2003). Fatal 


\section{Lamiaa M. Abd EL-Maoula et al.}

hepatic failure following accidental tramadol overdose. Forensic Sci. Int. 134: 232-235.

Miotto, K.; Cho, A.K.; Khalil, M.A.; Blanco, K.; Sasaki, J.D. and Rawson, R. (2017). Trends in tramadol: pharmacology, metabolism, and misuse. Anesth. Analg., 124:44-51

Moon, J.K. and Shibamoto, T. (2009). Antioxidant assays for plant and food components. J. Agric. Food Chem., 57(5):1655-1666.

Moshage, H.; Kok, B.; Huizenga, J.R. and Jansen, P.L. (1995). Nitrite and nitrate determinations in plasma: a critical evaluation. Clin. Chem., 41 (6Pt1):892-6.

Niesters, M.; Overdy, k.F.; Smith, T.; Aarts, L. and Dahan, A. (2013). Opioidinduced respiratory depression in pediatrics: a review of case reports. Br. J. Anaesth., 110(2): 175-182.

Oka, V.; Udefa, A.; Nna, V. and Owu, D. (2015). Sildenafil Citrate and Tramadol Administered Separately and in Combination Affects Basal Metabolic Rate, Triiodothyronine (T3) and Cortisol Levels in Albino Wistar Rats. Trends in Medical Res. 10: 51-62.

Padalia, S.; Drabu, S.; Raheja, I. and Gupta, A. (2010). Multitude potential of Wheat grass Juice (Green Blood): An overview. Chron. Young Sci., $1(2): 23-28$.

Pinho, S.; Oliveira, A.; Costa, I.; Gouveia, C.A.; Carvalho, F.; Moreira, R.F. and Dinis-Oliveira, R.J.(2013). Simultaneous quantification of tramadol and O-desmethyl tramadol in hair samples by gas chromatography-electron impact/ mass spectrometry. Biomed. Chromatogr., 27:1003-1011.
Raffa, R.B. (2008). Basic pharmacology relevant to drug abuse assessment: tramadol as an example. J. Clin. Pharm. Ther., 33:101-108.

Reitman, S. and Frankel, S. (1957). A colorimetric method for the determination of serum glutamic oxaloacetic and glutamic pyruvic transaminases. Am. J. Clin. Path., 28: 56.

Roy, S.E. (1970). Colorimetric determination of serum alkaline phosphatase. Clin. Chem., 16: 431-432.

Sachin, S.; Kumar, S.V.; Archana, S. and Shrivastav, B.R. (2013). Therapeutic of potential of wheatgrass (Tritium aestivum) against oxidative stress by platinum containing drugs during cancer chemotherapy: A future prospective. Int. Ayurvedic Med. J., 1(5):1- 5.

Salahshoor, M.R.; Khashiadeh, M.; Roshankhah, S.; Kakabaraeim, S. and Jalili, C. (2016). Protective effect of crocin on liver toxicity induced by morphine. Res. Pharm. Sci., 11:120-129.

Sareen, M.; Baghla, P.; Dhaka, P.; Mathur, E.; Sobti, P. and Khajuria, S. (2014).Wheat grass-a wonder herb. Syst. Rev. Pharm., 5(1):4.

Seo, W.D.; Yuk, H.J.; Curtis-Long, M.J.; Jang, K.C.; Lee, J.H.; Han, S.I.; Kang, H.W.; Nam, M.H.; Lee, S.J. and Lee, J.H. (2013). Effect of the growth stage and cultivar on policosanol profiles of barley sprouts and their adenosine 5'monophosphate-activated proteinkinase activation. J. Agric. Food Chem., 61:1117-1123.

Shaikh, M.R.N. and Majaz, Q. (2016). Hypoglycemic effect of wheat grass juice in aloxan induct diabetic rats. FS Pharma. Res., 1(2): 39-40. 
Shakya, G.; Goud, C.; Pajaniradje, S. and Rajagopalan, R. (2012). Protective role of wheatgrass on oxidative stress in streptozotocin induced type 2 diabeticrats. Int. J. Pharm. Pharmac. Sci., 4 (3):415-423.

Simeonova, R.; Kondeva-Burdina, M.; Vitcheva, V.; Krasteva, I.; Manov, V. and Mitcheva, M. (2014). Protective effects of the apigenin$\mathrm{O} / \mathrm{C}$-diglucosidesaponarin from Gypsophila trichotoma on carbone tetrachloride-induced hepatotoxicity in vitro/in vivo in rats. Phytomedicine, 21(2): 148-154.

Sonnenwirth, A. and Jaret, L. (1980). Grad wholes Clinical Laboratory Methods and Diagnosis. Vol. 18th, Ed. Mosby, London 258-259.

Spencer, K. and Price, C.P. (1977). Determination of serum albumin. Ann. Clin. Biochem., 14:105.

Templer, S.E.; Ammon, A. and Pscheidt, D. (2017). Metabolite profiling of barley flag leaves under drought and combined heat and drought stress reveal metabolic QTLs for metabolites associated with antioxidant defense. J. Exp. Botany, 68(7):1697-1713.

Watson, W.; Litovitz, T.L.; Klein-Schwartz, W.; Rodgers, G.C.; Youniss, J. and Reid, N. (2004). Annual report of the American Association of Poison Control Centers Toxic Exposure Surveillance System (Ultram). Am. J. Emerg. Med., 22:335-404.

Wheat, J. and Currie J. (2008). Herbal medicine for cancer patients: an evidence based review. Int. J. Altern. Med., 5:28-30.

Yang, X.; James, L.; Shi, Q. and Salminen, W.F. (2014). Biomarkers in Toxicology. Elsevier BV; Amsterdam, The Netherlands: Hepatic toxicity biomarkers; pp. 241-259.

Zuo, Y.; Zeng, Y, and Pu, X. (2017). Strategies of functional foods for heart disease prevention in human beings, in Proceedings from the ICERP 2016: International Conference on Environmental Research and Public Health of De Gruyter Open, pp. 108-123, Warsaw, Poland. 
Lamiaa M. Abd EL-Maoula et al.

\section{التأثيرات الوقائية لحشائش القـح والثعير على التسمم الكبدى المحدثبالترامادول في ذكور الجرذان}

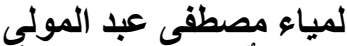



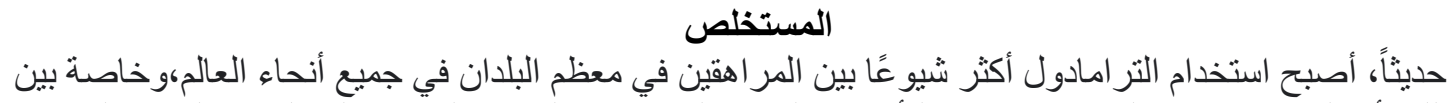

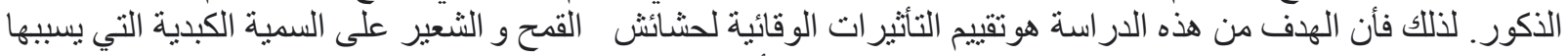

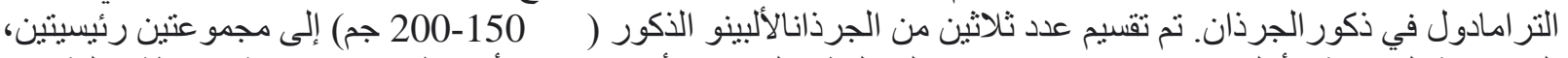

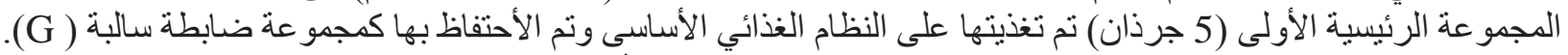

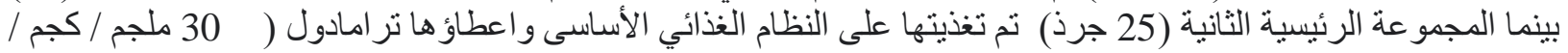

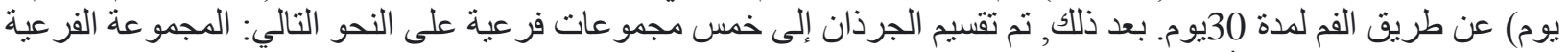

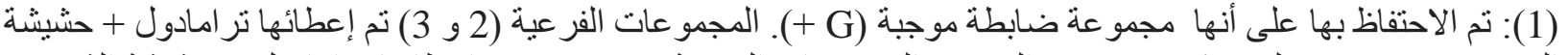

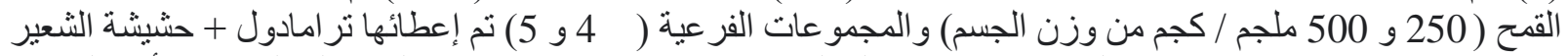

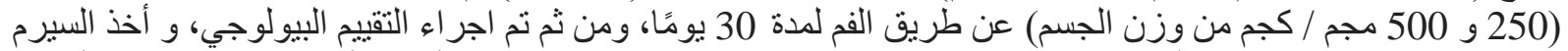



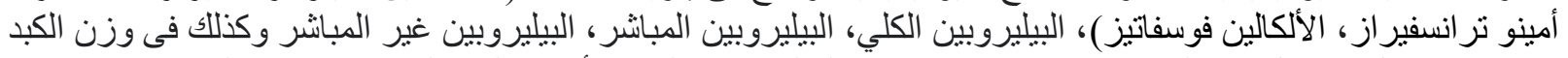

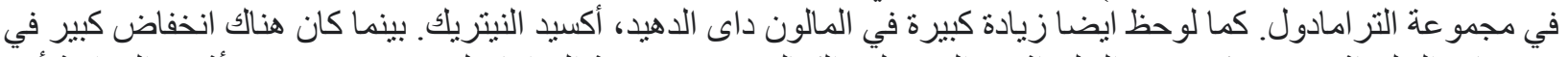

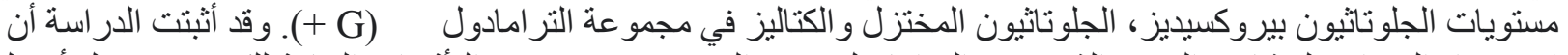

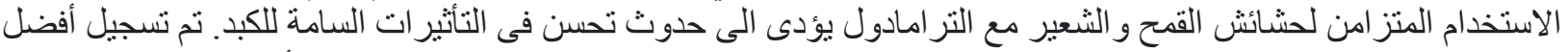

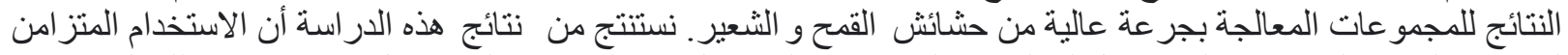

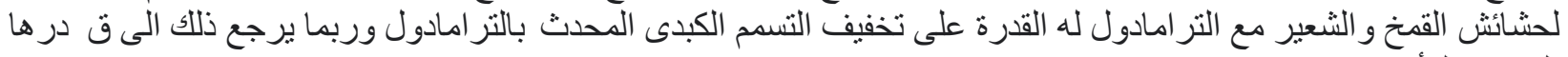
المضادة للأكسدة.

الكلمات المفتاحية: التسمم الكبدى , التر امادول , انزيمات الكبد , انزيمات مضادات الأكسدة , حشيشة القمح , حشيشة الشعير. 